\title{
SHOULD ACTIVE INJECTING DRUG USERS RECEIVE TREATMENT FOR CHRONIC HEPATITIS C?
}

\author{
Vasileios PAPADOPOULOS, Aikaterini GOGOU, Theodora MYLOPOULOU and \\ Konstantinos MIMIDIS
}

\begin{abstract}
Context - Accumulating data propose that active injecting drug users might not differ from the general population in terms of sustained virological response when adherent to therapy for chronic hepatitis C. However, current guidelines contain restrictive recommendations for therapy in this group of patients. Objective - Therefore, we evaluated a cohort of chronic hepatitis $\mathrm{C}$ patients regarding the potent influence of active drug using on initial informed consent, compliance and sustained virological response to treatment. Method - For that purpose, 162 consecutive patients (of which 62 active injecting drug users), who had been evaluated during the last 6 years in our center for chronic hepatitis $C$ and proposed to receive treatment with pegylated interferon alpha and ribavirin, were enrolled. Initial informed consent, compliance, and sustained virological response as well as data regarding age, gender, body mass index, genotype, viral load, coinfection with HBV/HDV/HIV, administered interferon alpha (2a or 2b), liver function tests, liver histology, urban residence, ethnicity, and concomitant use of alcohol were collected and analyzed in respect with injecting drug using. Results - Injecting drug using was positively correlated with male gender $(P<0.001)$, young age $(P<0.001)$, native origin $(P=0.043)$, and concomitant use of alcohol $(P<0.001)$. Comparable initial informed consent $(P=0.836)$, compliance $(P=0.879)$, and sustained virological response $(P=0.132)$ were observed between injecting drug users and non- injecting drug users. The results were confirmed using a multiple regression model. Conclusion - Our data further support that active injecting drug users do not constitute a distinct chronic hepatitis $\mathrm{C}$ patient group in terms of initial informed consent, compliance, or sustained virological response. Therefore, injecting drug using should not be a major determinant influencing the decision for treatment of chronic hepatitis $\mathrm{C}$ in eligible patients.
\end{abstract}

HEADINGS - Hepatitis C, chronic. Interferon Alfa-2. Ribavirin. Drug users.

\section{INTRODUCTION}

Hepatitis $\mathrm{C}$ virus (HCV) transmission is mainly attributed to intravenous drug abuse in developed countries, where $80 \%-90 \%$ of intravenous drug users are estimated to be positive for anti-HCV antibodies. Thus, there is much urge to identify and treat drug addicts with chronic hepatitis $\mathrm{C}(\mathrm{CHC})$. However, in this group of patients, coinfection with hepatitis $\mathrm{B}$ virus (HBV), hepatitis D virus (HDV), and human immunodeficiency virus (HIV), along with alcohol abuse, and psychiatric illnesses (sometimes aggravated by interferon), may impact negatively on the evolution of $\mathrm{HCV}$ infection, and the complience to therapy, necessitating a rather multidisciplinary setting $\mathrm{g}^{(3,5,8,12,13)}$

As indicated in recent studies, the treatment of $\mathrm{CHC}$ with peginterferon plus ribavirin in opiate addicts under methadone and/or buprenorphine maintenance therapy is well tolerated and offers a fairly good success rate, provided that close cooperation with specialists in drug addiction and psychiatrists is provided ${ }^{(3,7)}$.

Despite the above mentioned results, among patients with $\mathrm{CHC}$ eligible for treatment, active injecting drug users, not receiving substitution therapy, still constitute a distinct group. Current European guidelines, with the exception of France, contain restrictive recommendations for therapy in patients actively injecting drugs ${ }^{(10)}$. Furthermore, these patients are usually excluded from clinical studies as they are believed to manifest high-risk behavior $^{(2,4,9)}$. Thus, the therapeutic algorithm of $\mathrm{CHC}$ still remains controversial in this group of patients.

In the present study, we evaluated a cohort of $\mathrm{CHC}$ patients regarding the potent influence of active drug using on initial informed consent, compliance and sustained viral response (SVR) to treatment.

First Department of Internal Medicine, Democritus University of Thrace, Alexandroupolis, GR-68100, Greece.

Financial support: None received

Correspondence: Konstantinos Mimidis, MD, PhD, Gastroenterologist - Democritus University of Thrace, 8, Chrisostomou Smirnis str., GR-68100 - Alexandroupolis, Greece. Email: kmimidi@med.duth.gr 


\section{METHODS}

One hundred and sixty-two consecutive patients, who had been evaluated during the last 6 years in our center for $\mathrm{CHC}$ and proposed to receive treatment with pegylated interferon alpha-2a or alpha-2b and ribavirin, were enrolled (Figure 1).

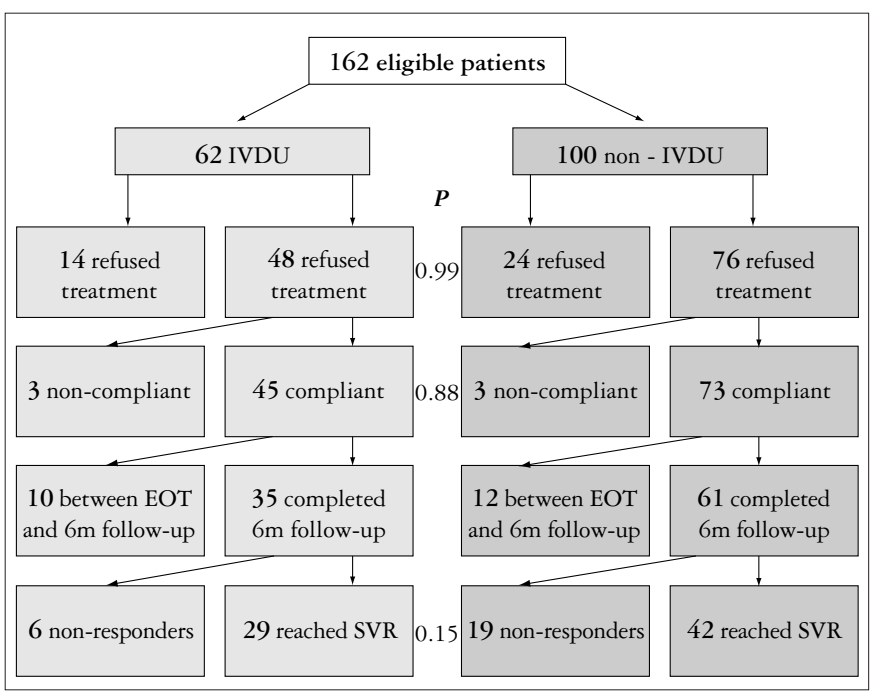

FIGURE 1. Study algorithm

Initial informed consent was asked by all patients enrolled. The study was approved by the Institutional Ethics Committee. In patients who provided informed consent, therapy with either pegylated interferon alpha $2 \mathrm{a}(180 \mu \mathrm{g} /$ week $)$ or alpha $2 \mathrm{~b}(1.5 \mu \mathrm{g} / \mathrm{kg} /$ week $)$ was administered subcutaneously along with ribavirin (twice daily, $800-1200 \mathrm{mg} /$ day) per os for $24-48$ weeks according to standard recommendations ${ }^{(11)}$. In case of relapse alternative treatment was offered. Compliance and SVR, considered as a negative HCV-RNA 24 weeks after the completion of treatment, were recorded for every patient. All patients were under close psychiatric observation througout the duration of the study.

Data regarding age, gender, $\mathrm{BMI}, \mathrm{HCV}$ genotype, coinfection with HBV, HDV, and HIV, administered pegylated interferon alpha ( $2 \mathrm{a}$ or $2 \mathrm{~b}$ ), urban residence, native (greek) origin, use of alcohol, and injecting drug using were collected. HCVRNA was determined using COBAS Amplicor HCV test, v.2.0 assay (Roche Molecular Systems, Branchburg, NJ, USA), a qualitative method with sensitivity of 60 copies $/ \mathrm{mL}$. HCV genotype was determined using INNO-LiPA HCV II kit (Bayer Diagnostics, Emeryville, CA, USA). Molecular diagnosis of HBV, HDV, and HIV was performed using similar techniques.

Evaluation was performed using chi-square along with Yates' correction where appropriate (absolute expected values $<5$ ) regarding discrete parameters and Student's $t$-test regarding continuous variables. However, in cases of nonnormality or non-uniformity of distributions, as exhibited by Kolmogorov-Smirnov and Lilliefors tests, respectively, the non-parametric Mann-Whitney U test was alternatively used.
Independent correlations were detected using appropriate multiple regression models. All mean values were accompanied by their standard errors. All $P$ values $<0.05$ were considered statistically significant. Statistical tests were performed with the statistical software package Statistica 6.0 and the on-line statistical tool freely available at www.statpages.org.

\section{RESULTS}

The cohort consisted of $62(38 \%)$ active injecting drug users (IDU) and $100(62 \%)$ non-injecting drug users (nonIDU) (Figure 1).

IDUs were younger than non-IDUs $(37.7 \pm 1.2$ vs $46.6 \pm 1.3$ years, $P<0.001)$. Moreover, the IDU group was characterized by a larger male/female ratio than the non-IDU group (54 males $/ 8$ females vs 57 males $/ 43$ females, $P<0.001)$. However, BMI was comparable between the two groups $(24.3 \pm 0.5$ vs $\left.25.2 \pm 0.4 \mathrm{~kg} / \mathrm{m}^{2}, P=0.152\right)$. Coinfection with HIV was not observed, while coinfection with HBV (positive HBV-DNA) was observed only in the IDU group (1/62 IDU patients, $P=0.203)$. Moreover, both the viral $\operatorname{load}(\log 10: 5.5 \pm$ 0.1 vs $5.7 \pm 0.1, P=0.293$ ) and the administered scheme (pegylated interferon alpha $2 \mathrm{a} / 2 \mathrm{~b}: 19 / 43$ vs $30 / 70, P=0.931$ ) were comparable between the two groups (IDU and nonIDU, consequently).

Injecting drug using was also positively correlated with native origin (44/62 vs 55/100, $P=0.043$ ), and concomitant use of alcohol (32/62 vs 19/100, $P<0.001)$. No difference was noticed between urban and rural residence $(42 / 58$ vs 74/96, $P=0.515)$.

As far as $\mathrm{HCV}$ genotypes were concerned, their distribution between IDUs and non-IDUs was similar (Table 1).

TABLE 1. HCV genotypes: comparison between IDU and non-IDU groups

\begin{tabular}{lccc}
\hline & IDU $(\mathrm{n}=62)$ & Non-IDU $(\mathrm{n}=100)$ & $P$-value \\
\hline Genotype 1 & $25 / 56$ & $39 / 83$ & 0.786 \\
Genotype 2 & $6 / 56$ & $14 / 83$ & 0.311 \\
Genotype 3 & $24 / 56$ & $24 / 83$ & 0.090 \\
Genotype 4 & $1 / 56$ & $6 / 83$ & 0.297 \\
\hline
\end{tabular}

Comparable informed consent $(P=0.836)$, compliance $(P=0.879)$, and SVR $(P=0.132)$ were observed between IDUs and non-IDUs (Table 2).

TABLE 2. Comparison between IDU and non-IDU groups

\begin{tabular}{lccc}
\hline & IDU $(\mathrm{n}=62)$ & Non-IDU $(\mathrm{n}=100)$ & $P$-value \\
\hline Age (years) & $37.7 \pm 1.2$ & $46.6 \pm 1.3$ & $<0.001$ \\
Gender (M: males, F: females) & $54 \mathrm{M} / 8 \mathrm{~F}$ & $57 \mathrm{M} / 43 \mathrm{~F}$ & $<0.001$ \\
BMI $\left(\mathrm{kg} / \mathrm{m}^{2}\right)$ & $24.3 \pm 0.5$ & $25.2 \pm 0.4$ & 0.152 \\
Urban residence & $42 / 58$ & $74 / 96$ & 0.515 \\
Native origin & $44 / 62$ & $55 / 100$ & 0.043 \\
Concomitant use of alcohol & $32 / 62$ & $19 / 100$ & $<0.001$ \\
Initial informed consent & $48 / 62(77.4 \%)$ & $76 / 100(76.0 \%)$ & 0.836 \\
Compliance & $45 / 48(93.8 \%)$ & $73 / 76(96.1 \%)$ & 0.879 \\
Response to treatment (SVR) & $29 / 35(82.9 \%)$ & $42 / 61(68.9 \%)$ & 0.132 \\
\hline
\end{tabular}


As the two groups were different at a statistically significant extent concerning age, gender ratio, native origin, and use of alcohol, a multiple regression model was used to distinguish primary, causative correlations from secondary, non-causative ones. In that model, injecting drug using, age, gender, BMI, genotype, urban residence, ethnicity, and concomitant use of alcohol, were considered as independent variables, while informed consent, compliance and SVR as dependent ones. None of the independent variables reveal any correlation with informed consent $(P=0.700)$, and compliance $(P$ $=0.545)$. However, genotype $2 / 3$ and younger age were independently correlated with better SVR, irrespectively of all other considered parameters $(P=0.002)$.

\section{DISCUSSION}

The present study demonstrates that active intravenous drug users constitute a group that might well be eligible for CHC treatment as they exhibit similar initial informed consent, compliance and SVR as non-users. This result is independent of any potent confounding factor, as a multiple regression method was used over data pre-estimated regarding comparability (groups of similar gender ratio, BMI, viral load, coinfection rates, and interferon used). Thus, what the study contributes to the perception of the $\mathrm{CHC}$ treatment algorithm in drug users, is that active drug using is not necessarily a barrier for the administration of the indicated therapeutic scheme (interferon alpha and ribavirin).

A previous study, carried out retrospectively in 500 patients, has also demonstrated that neither active intravenous drug using, nor substitution therapy reduces SVR rates in adherent CHC patients ${ }^{(4)}$. However, data concerning initial behavior regarding informed consent and enrollment to therapy, in relation with active drug using, was not reported.

The transmission of $\mathrm{HCV}$ is mainly attributed to the initial phase of drug using, where the awareness for viral disease transmission by reused syringes is limited ${ }^{(1,}$ ${ }^{6}$. The exact percentage of active intravenous drug users who, despite the achievement of SVR after treatment for $\mathrm{CHC}$, will be reinfected by $\mathrm{HCV}$, remains a question to be answered. Most possibly, the follow-up of our series of patients can provide some data on this subject, in the light of an excellent response to therapy with interferon/ ribavirin of acute hepatitis C $(90 \%)^{(9)}$.

In conclusion, our data support that active IDU do not constitute a distinct $\mathrm{CHC}$ patient group in terms of informed consent, compliance, or SVR. Moreover, in our patients, HCV genotypes were uniformly distributed among IDU and nonIDU. Therefore, injecting drug using should not be a major determinant influencing the decision for treatment of $\mathrm{CHC}$ in eligible patients.

Papadopoulos V, Gogou A, Mylopoulou T, Mimidis K. Usuários ativos de drogas injetáveis devem receber tratamento para hepatite crônica tipo C? Arq Gastroenterol. 2010;47(3):238-41.

RESUMO - Contexto - Dados acumulados demonstram que usuários ativos de drogas injetáveis podem não diferir da população em geral em termos de resposta virológica sustentada quando aderentes à terapia para a hepatite crônica C. No entanto, as atuais orientações publicadas contêm recomendações restritivas para a terapia nesse grupo de pacientes. Objetivo - Com este propósito, avaliou-se uma coorte de pacientes com hepatite crônica C após consentimento informado inicial, no que diz respeito à influência da droga ativa na adesão e na resposta virológica sustentada ao tratamento. Métodos - Para o efeito, foram convidados 162 pacientes (dos quais 62 ativos usuários de drogas injetáveis), que foram avaliados durante os últimos 6 anos em um centro de referência para a hepatite crônica $\mathrm{C}$ e se propuseram a receber tratamento com interferon alfa peguilado e ribavirina. $\mathrm{O}$ consentimento inicial, a adesão ao tratamento e a resposta virológica sustentada, bem como dados sobre idade, sexo, índice de massa corporal, genótipo, carga viral, com coinfecção HBV/HDV/HIV, tipo de interferon alfa administrado (2a ou 2b), testes de função hepática, histologia hepática, residência urbana, etnia e uso concomitante de álcool foram coletados e analisados em relação com o uso de drogas injetáveis. Resultados - O uso de drogas injetáveis teve correlação positiva com o sexo masculino $(P<0,001)$, idade $(P<0,001)$, de origem nativa $(P=0,043)$ e uso concomitante de álcool $(P<0,001)$. Foram observados entre usuários de drogas injetáveis e usuários de drogas não-injetáveis dados comparáveis em relação ao consentimento informado inicial $(P=0,836)$, adesão $(P=0,879)$ e resposta virológica sustentada $(P=0,132)$. Os resultados foram confirmados através de um modelo de regressão múltipla. Conclusão - Os dados confirmam ainda que usuários ativos de drogas injetáveis não constituem um grupo distinto de paciente com hepatite crônica $\mathrm{C}$ em termos de consentimento inicial, adesão, ou a resposta virológica sustentada. Assim, o uso de drogas injetáveis não deve ser um dos principais determinantes que influenciam a decisão para o tratamento da hepatite $\mathrm{C}$ crônica em pacientes elegíveis.

DESCRITORES - Hepatite C crônica. Interferon alfa 2a. Ribavirina. Usuário de drogas.

\section{REFERENCES}

1. Backmund M, Reimer J, Meyer K, Gerlach JT, Zachoval R. Hepatitis C virus infection and injection drug users: prevention, risk factors, and treatment. Clin Infect Dis. 2005;40(Suppl 5):s330-5.

2. Belfiori B, Chiodera A, Ciliegi P, Tosti A, Baldelli F, Stagni G, Francisci D. Treatment for hepatitis $\mathrm{C}$ virus in injection drug users on opioid replacement therapy: a prospective multicenter study. Eur J Gastroenterol Hepatol. 2007;19: $731-2$.
3. Belfiori B, Ciliegi P, Chiodera A, Bacosi D, Tosti A, Baldelli F, Francisci D. Peginterferon plus Ribavirin for chronic hepatitis $\mathrm{C}$ in opiate addicts on methadone/ buprenorphine maintenance therapy. Dig Liver Dis. 2009;41:303-7.

4. Bruggmann P, Falcato L, Dober S, Helbling B, Keiser O, Negro F, Meili D; Swiss Hepatitis Cohort Study. Active intravenous drug use during chronic hepatitis $\mathrm{C}$ therapy does not reduce sustained virological response rates in adherent patients. J Viral Hepat. 2008;15:747-52.

5. Jack K, Willott S, Manners J, Varnam MA, Thomson BJ. A primary-care-based model for the delivery of anti-viral treatment to injecting drug users infected with hepatitis C [abstract]. Aliment Pharmacol Ther 2008; 29:38-45. 
6. Jauffret-Roustide M, Le Strat Y, Couturier E, Thierry D, Rondy M, Quaglia M, Razafandratsima N, Emmanuelli J, Guibart G, Barin F, Desenclos LC. A national cross-sectional study among drug-users in France: epidemiology of HCV and highlight on practical and statistical aspects of the design. BMC Infect Dis. 2009;9:113.

7. Mauss S, Berger F, Goelz J, Jacob B, Schmutz G. A prospective controlled study of interferon-based therapy of chronic hepatitis $\mathrm{C}$ in patients on methadone maintenance. Hepatology. 2004;40:120-4.

8. Reimer J, Schulte B, Castells X, Schafer I, Polywka S, Hedrich D, Wiessing L, Haasen C, Backmund M, Krausz M. Guidelines for the treatment of hepatitis C virus infection in injection drug users: status quo in the European Union countries. Clin Infect Dis. 2005;40(Suppl 5):s373-8.

9. Reimer J, Haasen C. Need-adapted HCV-treatment setting for injection drug users. Lancet. 2009;373:2090-1.
10. Santantonio T, Wiegand J, Gerlach JT. Acute hepatitis C: current status and remaining challenges. J Hepatol. 2008;49:625-33.

11. Yu ML, Chuang WL. Treatment of chronic hepatitis C in Asia: when East meets West. J Gastroenterol Hepatol. 2009;24:336-45.

12. Zanini B, Lanzini A. Antiviral treatment for chronic hepatitis $\mathrm{C}$ in illicit drug users: a systematic review. Antivir Ther. 2009;14:467-79.

13. Zule WA, Costenbader EC, Coomes CM, Wechsberg WM. Effects of a hepatitis $\mathrm{C}$ virus educational intervention or a motivational intervention on alcohol use, injection drug use, and sexual risk behaviors among injection drug users. Am J Public Health. 2009;99(Suppl 1):s180-6.

Received 9/9/2009.

Accepted 6/1/2010. 